\title{
Analisis Faktor-Faktor Konversi Lahan Pertanian Di Kabupaten Tangerang Dengan Menggunakan Geographically Weighted Regression
}

\author{
Hadistian $^{1 *}$, Cahyadi Setiawan ${ }^{1}$ dan Aris Munandar ${ }^{1}$
}

${ }^{1}$ Program Studi Pendidikan Geografi, Fakultas Ilmu Sosial, Universitas Negeri Jakarta, Jakarta Timur, Indonesia.

${ }^{\star}$ Email korespodensi : Hadistian8@gmail.com,

Direvisi: 2020-08-11 Diterima: 2021-04-01

(C)2021 Fakultas Geografi UGM dan Ikatan Geograf Indonesia (IGI)

\begin{abstract}
Abstrak. Proses terjadinya konversi lahan pertanian dapat disebabkan oleh faktor internal dan eksternal yang berpengaruh terhadap perubahan luas lahan. Faktor kependudukan dan perekonomian diketahui sebagai salah satu faktor eksternal penyebab terjadinya konversi lahan pertanian menjadi non-pertanian. Salah satu wilayah yang mengalami konversi lahan pertanian ialah di Kabupaten Tangerang. Penelitian ini bertujuan untuk mengetahui faktor eksternal yang mempengaruhi konversi lahan pertanian. Metode penelitian menggunakan kuantitatif asosiatif dengan teknik analisis data statistik melalui model Geographically Weighted Regression. Pengumpulan data dilakukan dengan cara survei instansional untuk mendapatkan data sekunder dari laporan atau publikasi instansi terkait penelitian. Hasil menunjukkan besaran nilai setiap variabel berbeda di tiap kecamatan serta perbedaan variabel yang mempengaruhi konversi lahan pertanian. Variabel laju pertumbuhan penduduk dan kepadatan penduduk berpengaruh terhadap konversi lahan pertanian di 24 kecamatan. Terdapat lima kecamatan yang hanya variabel kepadatan penduduk berpengaruh terhadap konversi lahan pertanian. Rumah tangga miskin diketahui tidak berpengaruh nyata terjadap konversi lahan pertanian di seluruh kecamatan.
\end{abstract}

Kata kunci : Faktor Eksternal, konversi lahan pertanian, geographically weighted regression

\begin{abstract}
The process of conversion of agricultural land can be caused by internal and external factors that affect changes in land area. Population and economic factors are known to be external factors causing the conversion of agricultural land to non-agricultural land. One of the areas experiencing conversion of agricultural land is Tangerang Regency. This study aims to determine the external factors that affect the conversion of agricultural land. The research method uses associative quantitative with statistical data analysis techniques through the Geographically Weighted Regression model. Data collection was carried out by means of institutional surveys to obtain secondary data from reports or publications from research-related institutions. The results show that the value of each variable is different in each district as well as differences in variables that affect the conversion of agricultural land. Population growth rate and population density variables affect the conversion of agricultural land in 24 districts. There are five districts where population density only affects the conversion of agricultural land. It is known that poor households have no significant effect on agricultural land conversion in all sub-districts.
\end{abstract}

Keywords: External Factors, Land Agriculture Conversion, Geographically Weighted Regression

\section{PENDAHULUAN}

Lahan telah menjadi kebutuhan primer manusia untuk pangan dan papan. Ketersediaan lahan yang cenderung tetap pada tingkatan administratif akan menimbulkan permasalahan dalam memenuhi kebutuhan masyarakat akan lahan. Pertumbuhan penduduk dan kebutuhan ekonomi yang terjadi pada masyarakat akan menekan ketersediaan lahan, terutama lahan pertanian. Kondisi demikian yang menyebabkan lahan pertanian dihadapkan pada masalah penurunan luas lahan akibat dikonversi ke penggunaan non pertanian (Irawan \& Ariningsih, 2015).

Peristiwa terjadinya konversi lahan pertanian ke non pertanian dapat disebabkan oleh dua faktor yakni faktor internal dan faktor eksternal yang saling melengkapi satu sama lain (Djoni, Suprianto, \& Cahrial, 2016). Faktor internal disebabkan oleh adanya kendala teknis karakteristik lahan, skala usaha tani, rentabilitas usaha tani dan persepsi masyarakat terhadap lahan pertanian serta proses framgmentasi lahan pertanian. Dalam faktor eksternal penyebab konversi lahan pertanian umumnya disebabkan oleh keadaan penduduk dan perekonomian pada suatu wilayah termasuk kebijakan pemerintah daerah.

Alih fungsi lahan pertanian umumnya terjadi pada daerah Rural-Urban Continuum yang kemudian akan berkembang menjadi Mega Urban Region. Wilayah 
Kabupaten Tangerang dikatakan sebagai Mega Urban Region dengan ciri seperti kepadatan penduduk yang tinggi, penduduk sebagian besar bergantung pada lahan pertanian sempit, transformasi kegiatan pertanian ke non-pertanian, mobilitas penduduk yang tinggi, interaksi yang tinggi antara perdesaan dan perkotaan serta percampuran guna lahan yang intensif antara permukiman dan kegiatan ekonomi lainnya (Fadjarajani, 2008).

Kabupaten Tangerang menjadi bagian dari Mega Urban Region Jabodetabek yang mengalami konversi lahan cukup tinggi akibat dari adanya laju pertumbuhan penduduk dan kegiatan perekonomian. Konversi lahan akan menjadi suatu masalah ketika terjadi pada lahan pertanian yang masih produktif. Hal ini dikarenakan proses konversi lahan pertanian cenderung bersifat permanen dan dapat menganggu ketersediaan pangan bagi masyarakat. Lahan pertanian pangan merupakan salah satu lahan produktif yang cenderung mengalami konversi lahan. Keberadaan lahan pertanian pangan dapat ditemukan pada lahan basah seperti sawah dan beberapa lahan kering. Pemanfaatan lahan kering untuk pertanian pangan dapat dijumpai pada daerah berupa tegalan dan ladang (Idjudin \& Marwanto, 2008; Irawan \& Pranadji, 2002).

Penurunan luas lahan pertanian di Kabupaten Tangerang dapat diketahui dari tahun 2009 dengan luas sebesar 59.819 Ha menjadi 45.412 Ha pada tahun 2018. Penurunan luas lahan menunjukkan terjadinya perubahan fungsi lahan pertanian ke non pertanian yang dapat mengancam ketersediaan pangan bagi masyarakat. Secara lebih lengkap terdapat pada Tabel 1.

Keadaan penduduk dan peningkatan perekonomian menjadi faktor eksternal penyebab konversi lahan pertanian akibat adanya perkembangan kegiatan masyarakat yang membutuhkan lahan. Kebutuhan lahan semakin meningkat dengan cepat sejalan perkembangan jumlah penduduk dan pertumbuhan ekonomi (Kurniasari \& Ariastita, 2014). Faktor kependudukan menjadi penyebab konversi lahan pertanian, sebagai akibat dari adanya pertumbuhan penduduk, pola persebaran penduduk serta perubahan struktur penduduk seperti kepadatan penduduk yang dapat meningkatkan perubahan lahan pertanian ke penggunaan non pertanian (Fadjarajani \& Singkawijaya, 2019).
Laju pertumbuhan penduduk Kabupaten Tangerang pada tahun 2010-2018 diketahui memiliki persentase tertinggi kedua setelah Kota Tangerang Selatan dengan pertambahan penduduk sebesar 3,28\% dan jumlah penduduk tertinggi di Provinsi Banten dengan jumlah 3.692.693 jiwa di tahun 2018. Laju pertumbuhan penduduk tersebut berada di atas provinsi yang hanya sebesar 1,94\% pada tahun 2018 (BPS Provinsi Banten, 2019b). Peningkatan penduduk yang terus terjadi akan memberi dampak terhadap permintaan lahan untuk permukiman demi memenuhi kebutuhan papan manusia. Kepadatan penduduk pada Kabupaten Tangerang turut menunjukkan peningkatan dari $2.801 \mathrm{jiwa} / \mathrm{km}^{2}$ pada tahun 2010 menjadi $3.649 \mathrm{jiwa} / \mathrm{km}^{2}$ di tahun 2018. Kepadatan penduduk yang semakin bertambah menunjukkan peningkatan luasan permukiman bagi penduduk (Prabowo, Bambang, \& Sudarno, 2020).

Perekonomian menjadi faktor eksternal lainnya yang menyebabkan terjadinya alih fungsi lahan pertanian. Kepemilikan lahan yang tidak begitu besar akan mendorong masyarakat untuk mengambil keputusan menjual lahannya (Ikhwanto, 2019). Keputusan menjual lahan oleh masyarakat dikarenakan pendapatan yang didapatkan dalam sektor pertanian tidak begitu besar dibandingkan dari luar sektor pertanian. Peristiwa alih fungsi lahan pertanian pada kasus ini umumnya terjadi pada petani yang berada di garis kemiskinan. Keadaan kemiskinan dapat mendorong petani miskin untuk menjual aset produktif dalam memenuhi kebutuhan dasar mereka (Sayeed, 2014). Penjualan lahan pertanian akibat kemiskinan umumnya dilakukan oleh petani dengan lahan yang sempit demi mencukupi kebutuhan rumah tangga (Darwis, 2008)

Berdasarkan latar belakang yang telah diberikan tersebut, maka penelitian ini bertujuan untuk mengetahui faktorfaktor eksternal yang berpengaruh terhadap konversi lahan pertanian di Kabupaten Tangerang. Peristiwa alih fungsi lahan juga tidak terlepas dari adanya kedekatan suatu wilayah dengan wilayah lainnya. Sesuai dengan Hulum Tobler I yang menyatakan segala sesuatu akan saling berhubungan satu dengan yang lain, tapi sesuatu yang lebih dekat akan memiliki pengaruh lebih kuat daripada sesuatu yang jauh (Tobler, 1970). Melihat keterkaitan antara satu wilayah dengan wilayah lainnya, menjadikan penggunaan analisis Geographically Weighted Regression (GWR) lebih relevan

Tabel 1. Luas Lahan Pertanian Kabupaten Tangerang Tahun 2009-2017 Dalam Ha

\begin{tabular}{cccc}
\hline Tahun & Luas Lahan Basah (Sawah) & $\begin{array}{c}\text { Luas Lahan Kering } \\
\text { (Tegalan dan Ladang) }\end{array}$ & Jumlah \\
\hline 2009 & 40.628 & 19.191 & 59.819 \\
2010 & 40.786 & 19.232 & 60.018 \\
2011 & 40.667 & 18.704 & 59.371 \\
2012 & 38.697 & 20.085 & 58.782 \\
2013 & 38.697 & 17.443 & 56.140 \\
2014 & 38.697 & 17.443 & 56.140 \\
2015 & 37.127 & 10.337 & 47.464 \\
2016 & 37.073 & 10.337 & 47.410 \\
2017 & 36.196 & 10.186 & 46.382 \\
2018 & 36.231 & 9.181 & 45.412 \\
\hline
\end{tabular}

Sumber: BPS Provinsi Banten, 2009-2018. 
untuk memetakan faktor eksternal yang mempengaruhi alih fungsi lahan pertanian pada tingkat kecamatan.

\section{METODE PENELITIAN}

Metode penelitian yang digunakan ialah kuantitatif dengan jenis penelitian asosiatif. Metode kuantitatif asosiatif dilakukan untuk mengetahui hubungan antara dua variabel bahkan lebih yang berfungsi untuk menjelaskan, memprediksi dan mengontrol suatu gejala (Anshori dan Iswati, 2017). Teknik pengumpulan data yang dilakukan melalui survei instansional dengan bertujuan mendapatkan data sekunder yang bersumber dari publikasi berkala, data ataupun arsip dari instansi penyedia data. Hasil data yang dihimpun berupa variabel yang didasarkan dari faktor eksternal penyebab alih fungsi lahan pertanian yakni laju pertumbuhan penduduk, kepadatan penduduk dan persentase rumah tangga miskin. Secara lebih jelas penggunaan variabel dapat dilihat pada tabel 2 .

Data variabel independen X1 dan X2 dihimpun dari publikasi Kabupaten Tangerang Dalam Angka pada terbitan tahun 2010 hingga tahun 2019. Variabel X3 menunjukkan perbedaan tahun penggunaan data dibandingkan dengan variabel lainnya, dikarenakan publikasi data terakhir dalam Kabupaten Tangerang Dalam Angka Tahun 2019 masih menggunakan data tahun 2017. Sumber data pada variabel dependen (Y) bersumber dari Luas Lahan Menurut Penggunaannya Tahun 2009-2018. Proses analisis data dilakukan melalui analisis statistik dengan pemodelan GWR yang dilakukan dilakukan sebagai berikut :

1. Analisis Faktor-Faktor yang Mempengaruhi Konversi Lahan Pertanian

Sebelum melakukan analisis GWR dilakukan pencarian nilai rasio berdasarkan variabel yang digunakan dengan cara :

Laju Pertumbuhan Penduduk $=\left(\frac{\mathrm{Pt}}{\mathrm{Po}}\right)^{\frac{1}{\mathrm{t}}}-1$
Kepadatan Penduduk $=\frac{\text { Jumlah Pendudul }}{\text { Luas Wilayah }}$
Persentase Rumah Tangga Miskin $=\frac{\text { Jumlah Rumah Tangga Miskin }}{\text { Jumlah Rumah Tangga }} \times 100 \%$

Setelah mengetahui nilai dari variabel diatas maka dilakukan analisis faktor-faktor yang mempengaruhi konversi lahan pertanian dengan beberapa tahap yakni :

a. Pengujian Ordinary Least Square (OLS)

Tes OLS dilakukan untuk mengetahui signifikansi tiap parameter yang berpengaruh terhadap variabel respon pada tingkat signifikansi sebesar 0,05. Pengujian serempak dilakukan untuk mengetahui ada atau tidaknya pengaruh seluruh parameter terhadap variabel respon dengan menggunakan taraf signifikansi 0,05.

b. Pengujian Asumsi Klasik

Dalam mencapai regresi yang Best Unbiased Liniear Estimation (BLUE) dilakukan pengujian asumsi klasik dengan cara :

1. Uji Normalitas

Pada penelitian pengujian normalitas dengan menggunakan Kolmogorov-Smirnov.

2. Uji Heteroskedastisitas

Pengujian yang dilakukan dalam mengetahui keragaman data menggunakan uji Glejser.

3. Uji Autokorelasi

Dalam mengetahui ada atau tidak korelasi antar data digunakan pengujian Durbin-Watson.

4. Uji Multikolinearitas

Tes yang dilakukan untuk mengetahui hubungan antara sesama variabel prediktor menggunakan nilai VIF serta angka tolerance.

c. Uji Efek Spasial

Pengujian efek spasial dilakukan dengan menggunakan pengujian depedensi spasial dan heterogrenitas spasial. Pengujian depedensi spasial menggunakan uji Moran's I dan heterogenitas spasial menggunakan uji Breuch-Pagan Test.

d. Pemodelan Geographically Weighted Regression (GWR)

Geographically Weighted Regression merupakan sebuah teknik dari pengembangan kerangka regresi tradisional dengan memasukkan variasi spasial dalam suatu tingkatan perubahan estimasi global menjadi parameter lokasi pada suatu titik I (Brunsdon, Fotheringham, \& Charlton, 1996). Penggunaan GWR didahului dengan menentukan penggunaan bobot terlebih dahulu. Pembobot yang digunakan ialah Fixed Kernel Gaussian.

\section{HASIL DAN PEMBAHASAN \\ Deskripsi Wilayah}

Kabupaten Tangerang diketahui memiliki wilayah administratif yang terbagi menjadi 29 kecamatan. Pusat kegiatan atau administrasi kabupaten terletak di Kecamatan Tigaraksa. Letak astronomis Kabupaten Tangerang terletak pada $6^{\circ} 00^{\prime}-6^{\circ} 20^{\prime}$ Lintang Selatan dan 106 20'-106 $43^{\prime}$ Bujur Timur dengan luas wilayah sebesar $959,60 \mathrm{~km}^{2}$. Kabupaten Tangerang berbatasan langsung dengan Laut Jawa di sebelah utara; Kabupaten Bogor pada bagian selatan; Kabupaten Serang dan Lebak di bagian barat; dan timur berbatasan dengan Kota Tangerang, Kota Tangerang Selatan dan Kota Jakarta Barat. Gambaran lebih jelas dapat dilihat pada gambar 1 .

Tabel 2. Jenis Data Penelitian

\begin{tabular}{|c|c|c|c|}
\hline Variabel & Jenis Data & Penjelasan Variabel & Sumber \\
\hline $\mathrm{X} 1$ & $\begin{array}{l}\text { Laju Pertumbuhan } \\
\text { Penduduk }\end{array}$ & $\begin{array}{l}\text { Rata-Rata Laju Pertumbuhan Penduduk 2009-2018 } \\
(\%)\end{array}$ & BPS Kabupaten Tangerang \\
\hline $\mathrm{X} 2$ & Kepadatan Penduduk & $\begin{array}{l}\text { Rata-Rata Kepadatan Penduduk 2009-2018 (jiwa/ } \\
\mathrm{km}^{2} \text { ) }\end{array}$ & BPS Kabupaten Tangerang \\
\hline $\mathrm{X} 3$ & Rumah Tangga Miskin & Rasio Rumah Tangga Miskin 2017 (\%) & BPS Kabupaten Tangerang \\
\hline $\mathrm{Y}$ & $\begin{array}{l}\text { Alih Fungsi Lahan } \\
\text { Pertanian }\end{array}$ & $\begin{array}{l}\text { Rata-Rata Perubahan Lahan Pertanian 2009-2018 } \\
\text { (Ha). }\end{array}$ & BPS Provinsi Banten \\
\hline
\end{tabular}

Sumber : Peneliti, 2020. 
Sosial-ekonomi masyarakat Kabupaten Tangerang memiliki keragaman dalam lapangan pekerjaan. Sektor industri pengolahan mendominasi lapangan pekerjaan masyarakat dengan total 610.153 jiwa. Keseluruhan jenis lapangan pekerjaan utama masyarakat dapat dilihat pada tabel 4 .

\section{Eksplorasi Data}

Laju pertumbuhan penduduk (X1) tertinggi dari tahun 2009-2018 di Kabupaten Tangerang diketahui terletak di Kecamatan Panongan yang sebesar 9,18\%. Pertumbuhan penduduk di Kecamatan Panongan lebih tinggi dibandingkan dengan pertumbuhan pada tingkat kabupaten yang sebesar 3,28 \%. Beberapa kecamatan di Kabupaten Tangerang diketahui memiliki pertumbuhan penduduk yang lebih rendah dibandingkan dengan angka pertumbuhan rata-rata kabupaten. Sebanyak tiga kecamatan memiliki pertumbuhan penduduk negatif yang terdapat pada Kecamatan Gunung Kaler (-0,14\%), Mekarbaru (-0,20\%) dan Sukadiri (-0,03\%). Data lebih lengkap tersaji pada tabel 5.

Kepadatan penduduk (X2) di Kabupaten Tangerang, diketahui sebesar 3.649 jiwa $/ \mathrm{km}^{2}$. Angka ini jauh dari ratarata Provinsi Banten yang sebesar $1.313 \mathrm{jiwa} / \mathrm{km}^{2}$. Kecamatan Pasar Kemis dalam rentang tahun 2009-2018 memiliki rataan kepadatan penduduk sebesar $11.135 \mathrm{jiwa} / \mathrm{km}^{2}$ dan menjadi-

Tabel 3. Penggunaan Lahan Kabupaten Tangerang Tahun 2018

\begin{tabular}{ll}
\hline Penggunaan Lahan & Luas Area $(\mathrm{Ha})$ \\
\hline Sawah & 36.231 \\
Lahan Kering & 59.759 \\
\hline
\end{tabular}

Sumber : BPS Kabupaten Tangerang (2019) dan BPS Provinsi Banten (2019a) kannya daerah dengan kepadatan penduduk tertinggi di kabupaten. Tingkat kepadatan penduduk terendah diketahui terdapat di Kecamatan Kemiri yang memiliki kepadatan penduduk sebesar 1.307 jiwa $/ \mathrm{km}^{2}$. Sebaran kepadatan penduduk secara lengkap dapat diketahui pada tabel 6 .

Rasio tertinggi rumah tangga miskin (X3) di Kabupaten Tangerang diketahui berada di Kecamatan Mekarbaru sebesar 39,19\%. Kecamatan Kelapa Dua memiliki rasio rumah tangga miskin terkecil dibandingkan kecamatan lainnya dengan angka sebesar 0,82\%. Secara keseluruhan rasio rumah tangga miskin berdasarkan kecamatan dapat dilihat pada tabel 7.

Analisis konversi lahan pertanian (Y) di Kabupaten Tangerang dihitung berdasarkan rata-rata perubahan luas lahan pertanian dari tahun 2009-2018. Kecamatan Pagedangan diketahui terjadi penurunan luas lahan pertanian tertinggi sebesar $229,667 \mathrm{Ha}$. Masih terdapat

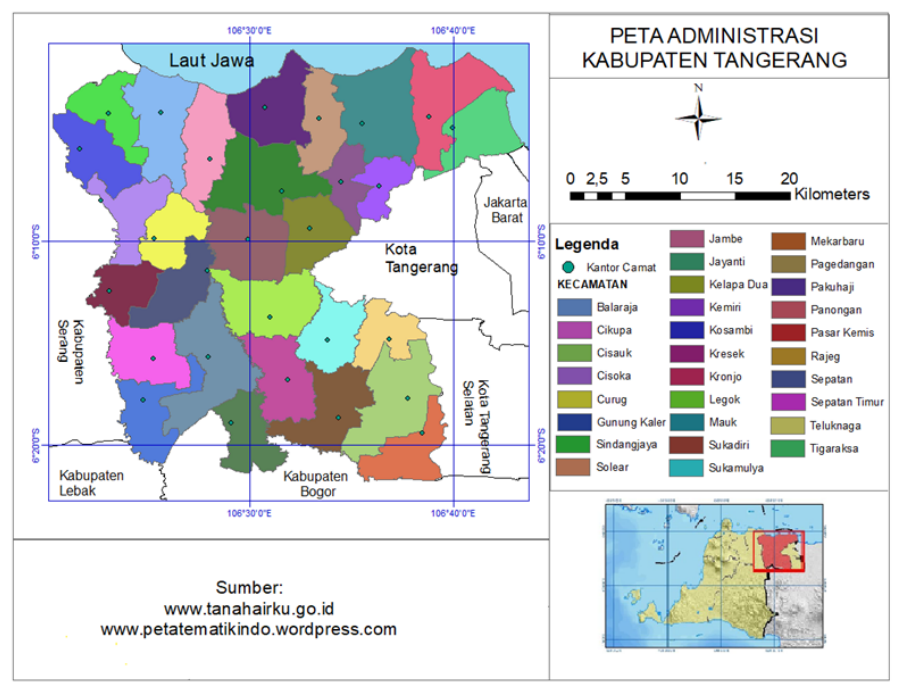

Gambar 1. Peta Administratif Kabupaten Tangerang

Tabel 4. Lapangan Pekerjaan Utama Masyarakat Kabupaten Tangerang Tahun 2018

\begin{tabular}{lr}
\hline Jenis Lapangan Pekerjaan & Jumlah \\
\hline Pertanian, Kehutanan dan Perikanan & 107.541 \\
Pertambangan dan Penggalian & 2.144 \\
Industri Pengolahan & 610.153 \\
Pengadaan Listik dan Gas & 4.761 \\
Pengadaan Air, Pengelolaan Sampah, Limbah dan Daur Ulang & 30.050 \\
Konstruksi & 83.154 \\
Perdagangan Besar dan Eceran & 275.447 \\
Trasnportasi dan Pergudangan & 85.152 \\
Penyediaan Akomodasi dan Makanan & 86.430 \\
Informasi dan Komunikasi & 13.984 \\
Jasa Keuangan dan Asuransi & 21.602 \\
Real Estate & 23.233 \\
Jasa Perusahaan & 30.690 \\
Adminitrasi Pemerintahan, Pertahanan dan Jaminan Sosial & 13.233 \\
Pendidikan & 57.226 \\
Kesehatan dan Kegiatan Sosial & 100.003 \\
Jasa Lainnya & 77.346 \\
\hline
\end{tabular}

Sumber : BPS Kabupaten Tangerang (2019) 
Tabel 5. Laju Pertumbuhan Penduduk 2009-2018 (\%) dan Jumlah Penduduk 2018

\begin{tabular}{|c|c|c|}
\hline Kecamatan & Laju Pertumbuhan 2009-2018 (\%) & Jumlah Penduduk 2018 (jiwa) \\
\hline Solear & 3,810 & 96.539 \\
\hline Teluknaga & 2,970 & 170.890 \\
\hline Tigaraksa & 5,770 & 167.487 \\
\hline Rajeg & 5,620 & 185.014 \\
\hline Sindangjaya & 3,720 & 99.460 \\
\hline Panongan & 9,180 & 152.506 \\
\hline Pagedangan & 4,700 & 124.624 \\
\hline Pasar Kemis & 7,220 & 362.258 \\
\hline Sepatan & 5,600 & 127.625 \\
\hline Sepatan Timur & 3,040 & 98.866 \\
\hline Curug & 5,000 & 222.226 \\
\hline KelapaDua & 6,640 & 245.110 \\
\hline Pakuhaji & 1,190 & 117.353 \\
\hline Mauk & 0,340 & 83.730 \\
\hline Mekarbaru & $-0,20$ & 38.647 \\
\hline Legok & 4,610 & 129.364 \\
\hline Jambe & 1,420 & 46.153 \\
\hline Jayanti & 2,500 & 75.324 \\
\hline Kemiri & 0,160 & 44.626 \\
\hline Kosambi & 5,030 & 172.674 \\
\hline Kresek & 0,340 & 66.685 \\
\hline Balaraja & 3,000 & 137.778 \\
\hline Cikupa & 4,800 & 298.421 \\
\hline Cisoka & 3,570 & 98.888 \\
\hline Gunungkaler & $-0,140$ & 53.524 \\
\hline Kronjo & 0,760 & 63.088 \\
\hline Sukadiri & $-0,030$ & 56.641 \\
\hline Sukamulya & 0,930 & 67.671 \\
\hline Cisauk & 7,690 & 89.521 \\
\hline
\end{tabular}

Sumber : Olah Data, 2020

beberapa wilayah lainnya yang mengalami peningkatan luas lahan pertanian seperti Kecamatan Balaraja (40,222 $\mathrm{Ha})$, Kecamatan Sukamulya (29,000 Ha), Kecamatan Kresek $(11,111 \mathrm{Ha})$ dan Kronjo (31,778 Ha). Secara lebih rinci luas lahan pertanian yang teralihfungsikan dapat dilihat pada tabel 8 .

Analisis Faktor yang Mempengaruhi Konversi Lahan Pertanian

Dalam melakukan analisis faktor yang mempengaruhi konversi lahan pertanian dengan menggunakan analisis GWR, terlebih dahulu dilakukan pengujian ordinary least square untuk mengetahui variabel yang berpengaruh terhadap variabel respon. Pengujian berikutnya dilakukan untuk memenuhi prasayarat regresi demi mendapatkan hasil yang BLUE (Best Linear Unbiased Estimation).

1.Ordinary Least Square (OLS)

Pengujian yang dilakukan terlebih dahulu ialah pengujian serentak dengan hasil berupa nilai signifikansi sebesar 0,004. Nilai tersebut dapat diartikan bahwa seluruh variabel secara bersamaan berpengaruh signifikan terhadap konversi lahan pertanian. Dalam pengujian secara parsial dapat diketahui bahwa hanya variabel laju pertumbuhan penduduk dan kepadatan penduduk yang berpengaruh signfikan. Rasio rumah tangga miskin tidak berpengaruh signifikan terhadap konversi lahan pertanian dengan nilai signifikansi sebesar 0,162.

2. Pengujian Asumsi Klasik

Hasil pengujian asumsi klasik diketahui bahwa hasil residual telah terdistribusi normal dengan nilai probability sebesar 0,200. Hasil analisis lainnya juga menunjukkan bahwa tidak terdapat multikolinearitas dengan nilai VIF kurang dari 10 dan nilai tolerance $\leq 1$. Pengujian lainnya diketahui bahwa residual terbebas dari adanya heteroskedastisitas dan terbebas dari autokorelasi. 3.Pengujian Efek Spasial

Hasil analisis dari pengujian efek spasial diketahui bahwa nilai Moran's I dalam mengetahui autokorelasi spasial bernilai 0,016. Hasil ini menunjukkan bahwa terdapat autokorelasi spasial dalam data. Adanya korelasi mengartikan bahwa nilai atribut pada daerah tertentu memiliki kaitannya dengan daerah lain yang letaknya berdekatan atau bertetangga (Lutfi, Aidid, \& Sudarmin, 2019).

Pada pengujian efek spasial berikutnya yakni heteroskedastisitas spasial dengan menggunakan Breuch-Pagan test didapati nilai probability sebesar 0,092 . Hasil pengujian dengan menggunakan probability sebesar 
Tabel 6. Rata-Rata Kepadatan Penduduk 2009-2018

\begin{tabular}{lrlr}
\hline Kecamatan & Kepadatan Penduduk $\left(\mathrm{Jiwa} / \mathrm{Km}^{2}\right)$ & Kecamatan & Kepadatan Penduduk $\left(\mathrm{Jiwa} / \mathrm{Km}^{2}\right)$ \\
\hline Solear & 2.886 & KelapaDua & 8.396 \\
Teluknaga & 3.763 & Balaraja & 3.668 \\
Tigaraksa & 2.856 & Cikupa & 5.978 \\
Rajeg & 2.876 & Cisoka & 3.242 \\
Sindangjaya & 2.335 & Gunungkaler & 1.730 \\
Panongan & 3.389 & Jambe & 1.660 \\
Pakuhaji & 2.126 & Jayanti & 2.881 \\
Mauk & 1.579 & Kemiri & 1.307 \\
Mekarbaru & 1.565 & Kosambi & 4.972 \\
Legok & 3.165 & Kresek & 2.469 \\
Pagedangan & 2.350 & Kronjo & 1.324 \\
PasarKemis & 11.135 & Sukadiri & 2.297 \\
Sepatan & 6.165 & Sukamulya & 2.357 \\
SepatanTimur & 4.879 & Cisauk & 2.658 \\
Curug & 6.897 & & \\
\hline
\end{tabular}

Tabel 7. Rasio Rumah Tangga Miskin Kabupaten Tangerang (\%)

\begin{tabular}{lrlr}
\hline Kecamatan & Rasio Rumah Tangga Miskin & Kecamatan & Rasio Rumah Tangga Miskin \\
\hline Solear & 17,410 & Kelapa Dua & 0,840 \\
Teluknaga & 15,540 & Balaraja & 6,030 \\
Tigaraksa & 9,870 & Cikupa & 1,120 \\
Rajeg & 16,630 & Cisoka & 17,090 \\
Sindangjaya & 17,160 & Gunung kaler & 29,980 \\
Panongan & 7,610 & Jambe & 17,200 \\
Pakuhaji & 25,810 & Jayanti & 11,980 \\
Mauk & 18,180 & Kemiri & 32940 \\
Mekarbaru & 39,190 & Kosambi & 8,210 \\
Legok & 8,990 & Kresek & 18,210 \\
Pagedangan & 6,620 & Kronjo & 25,390 \\
Pasar Kemis & 2,070 & Sukadiri & 14,930 \\
Sepatan & 8,630 & Sukamulya & 21,740 \\
Sepatan Timur & 16,830 & Cisauk & 9,430 \\
Curug & 1,260 & \\
\hline
\end{tabular}

Sumber : Olah Data, 2019

0,100 diketahui terdapat keragaman struktur dan parameter yang berbeda pada setiap lokasi pengamatan (random region effect).

4. Pengujian Geographically Weighted Regression (GWR) Analisa dengan menggunakan GWR terlebih dahulu menentukan bobot yang digunakan. Penggunaan bobot yang digunakan ialah Fixed Kernel Gaussian. Penentuan besaran bobot didapatkan dari nilai bandwith yang melalui proses Cross Validation (CV). Penggunaan Fixed Kernel Gaussian akan menghasilkan parameter pengendalian kunci yang menunjukkan ketetapan jarak (Lu, Charlton, Harris, \& Fotheringham, 2014). Pada hasil penganalisaan diketahui bandwith yang digunakan 18,612 dengan nilai CV minimum sebesar 3.628,213. Hasil analisis perbedaan antara OLS dan GWR ditampilkan pada tabel 9.

Tabel 9, menunjukkan bahwa nilai $\mathrm{F}$ hitung yang dihasilkan sebesar 1,711746. Kriteria penarikan kesimpulan digunakan nilai alpha sebesar $10 \%$ dengan nilai f-tabel yakni
$F_{\text {hitung }}>F_{(\alpha ; 25,000 ; 23,752)}=1,710107$. Maka dengan angka tersebut dapat dikatakan bahwa terdapat perbedaan yang signifikan antara model OLS dengan model GWR. Pengujian untuk mendapatkan model terbaik turut dilakukan dengan menggunakan goodness of fit test. Secara konvensional pengujian goodness of fit test dilakukan dengan membandingkan nilai $\mathrm{R}^{2}$ (Huang, Wu, \& Barry, 2010).

Alternatif lainnya dalam mengetahui model terbaik antara nilai OLS dan GWR dapat menggunakan komparasi nilai Akaike Informasi Criteria (AIC) dari kedua model tersebut. Hal ini juga terdapat dalam penelitian yang dilakukan Saefuddin et.al (2011) yang menjelaskan bahwa dalam membandingkan kinerja model GWR dan OLS dapat menggunakan koefisien determinasi $\left(\mathrm{R}^{2}\right)$ dan statistik Akaike Information Criteria (AIC).

Berdasarkan tabel 10, dapat diketahui bahwa nilai AIC model GWR lebih kecil secara matematis dibandingkan dengan AIC model OLS. Model GWR terbukti dapat 
Tabel 8. Rata-Rata Luas Lahan Pertanian Teralihfungsikan (Ha)

\begin{tabular}{lrlr}
\hline Kecamatan & Lahan Terkonversi (Ha) & Kecamatan & Lahan Terkonversi (Ha) \\
\hline Solear & $-11,670$ & Cisoka & $-46,670$ \\
Teluknaga & $-79,330$ & Gunung kaler & $-1,890$ \\
Tigaraksa & $-224,440$ & Jambe & $-72,000$ \\
Rajeg & $-59,110$ & Jayanti & $-16,670$ \\
Sindangjaya & $-51,560$ & Kemiri & $-5,110$ \\
Panongan & $-168,890$ & Kosambi & $-32,670$ \\
Pakuhaji & $-79,440$ & Kresek & 11,110 \\
Mauk & $-41,220$ & Pasar Kemis \\
Mekarbaru & $-47,440$ & Sepatan & $-30,780$ \\
Legok & $-65,000$ & Sepatan Timur & $-69,560$ \\
Pagedangan & $-229,670$ & Cisauk & $-22,780$ \\
Curug & $-134,560$ & Kronjo & $-63,670$ \\
Kelapa Dua & $-57,560$ & Sukadiri & 31,780 \\
Balaraja & 40,220 & Sukamulya & $-8,780$ \\
Cikupa & $-92,440$ & & 29,000 \\
\hline
\end{tabular}

Sumber : Olah Data, 2020

Tabel 9. Hasil Analysis of Variance GWR

\begin{tabular}{lllll}
\hline Source & Sum Square & DF & Mean Square & F \\
\hline Global Residual & 74772,040 & 25,00 & & \\
GWR Improvement & 6171,441 & 1,248 & 4943,930 & \\
GWR Residual & 68600,599 & 23,752 & 2888,238 & 1,711746 \\
\hline
\end{tabular}

Tabel 10. Goodness of Fit Test

\begin{tabular}{lll}
\hline Kriteria & Regresi Linear (OLS) & GWR \\
\hline AIC & 320,090635 & 318,963649 \\
$\mathrm{R}^{2}$ & 0,392487 & 0,442629 \\
\hline
\end{tabular}

Sumber : Hasil Penelitian, 2020.

meningkatkan nilai $\mathrm{R}^{2}$ dibandingkan pada penggunaan model OLS. Hasil perbandingan mengindikasikan bahwa pemodelan yang dilakukan dengan menggunakan GWR dapat dikatakan sebagai model yang lebih baik dibandingkan pemodelan oleh OLS.

Hasil pemodelan GWR memerlukan penggambaran dalam bentuk peta dikarenakan memiliki peran dalam menafsirkan serta menganalisis hasil uji yang dilakukan (Mennis, 2006). Dalam gambar 2, ditampilkan persebaran $\mathrm{R}^{2}$ yang menandakan besaran pengaruh variabel independen secara serentak terhadap variabel dependen.

Hasil $\mathrm{R}^{2}$ pada gambar 2, menjelaskan bahwa bagian barat Kabupaten Tangerang memiliki angka yang lebih besar dibandingkan dengan bagian timur kabupaten. Semakin kecilnya nilai pada bagian timur kabupaten dapat dijelaskan bahwa area tersebut lebih memiliki banyak faktor yang mempengaruhi konversi lahan pertanian dibandingkan dengan bagian wilayah barat. Banyaknya faktor ini tidak terlepas dari dekatnya wilayah timur Kabupaten Tangerang terhadap beberapa perkotaan besar seperti Jakarta Utara,
Jakarta Barat, Kota Tangerang dan Kota Tangerang Selatan yang memberi dampak semakin kompleksnya penyebab konversi lahan pertanian.

Analisis per variabel dilakukan dengan menampilkan peta nilai-t dan nilai estimasi pada setiap wilayah. Interpretasi pada gambar 3, memperlihatkan besaran nilai variabel laju pertumbuhan penduduk yang diketahui dari nilai-t dengan nilai berkonotasi negatif.

Nilai-t yang negatif dapat dijelaskan bahwa peningkatan konversi lahan pertanian akibat dari adanya pengembang kawasan atau kegiatan pribadi bukan hanya dari pertumbuhan penduduk, tetapi sebagai hasil suatu proses investasi bagi masyarakat berpendapatan tinggi yang saat ini menjadi trend dalam masyarakat di sekitar perkotaan (Ilham et al., 2005). Dalam penelitian lain diketahui terdapat pengaruh negatif pertumbuhan penduduk terhadap konversi lahan pertanian di Kota Marisa, Kabupaten Pohuwato (Wunarlan \& Syaf, 2019). Pada hasil pengujian secara parsial diketahui bahwa laju pertumbuhan penduduk di seluruh 
kecamatan memiliki pengaruh yang signifikan di seluruh kecamatan dengan taraf signifikansi sebesar 0,05.

Persebaran nilai-t pada gambar 4, menunjukkan nilai yang positif serta nilai estimasi dari kepadatan penduduk. Nilai-t yang positif menunjukkan semakin tingginya kepadatan penduduk akan meningkatkan alih fungsi lahan pertanian. Pengaruh kepadatan penduduk berpusat pada area timur kabupaten yang berdekatan dengan pusat perdagangan di Kota Tangerang Selatan dan industri yang terdapat di Kota Tangerang. Adanya kegiatan perekonomian memberi peningkatan laju pertumbuhan penduduk akibat dari semakin

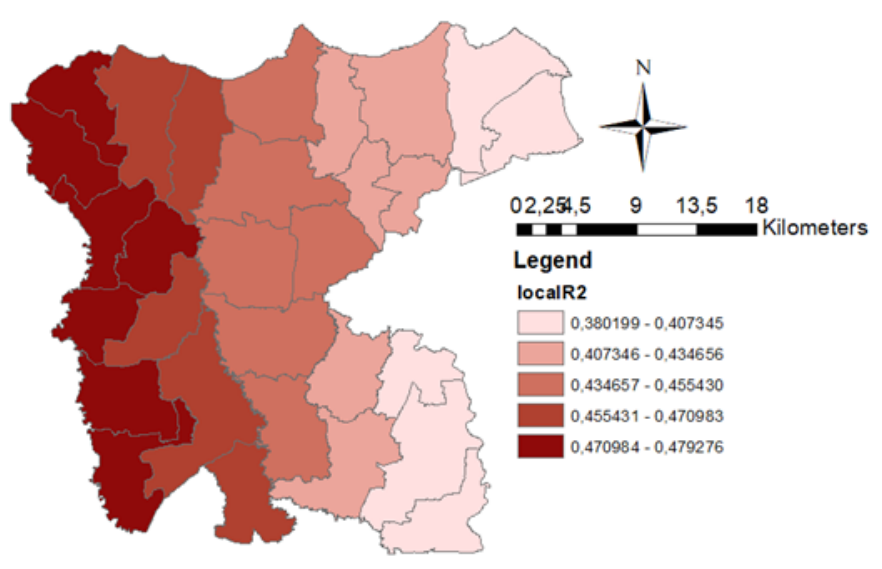

Gambar 2. Peta Administrasi dan $\mathrm{R}^{2}$ lokal per Kecamatan.

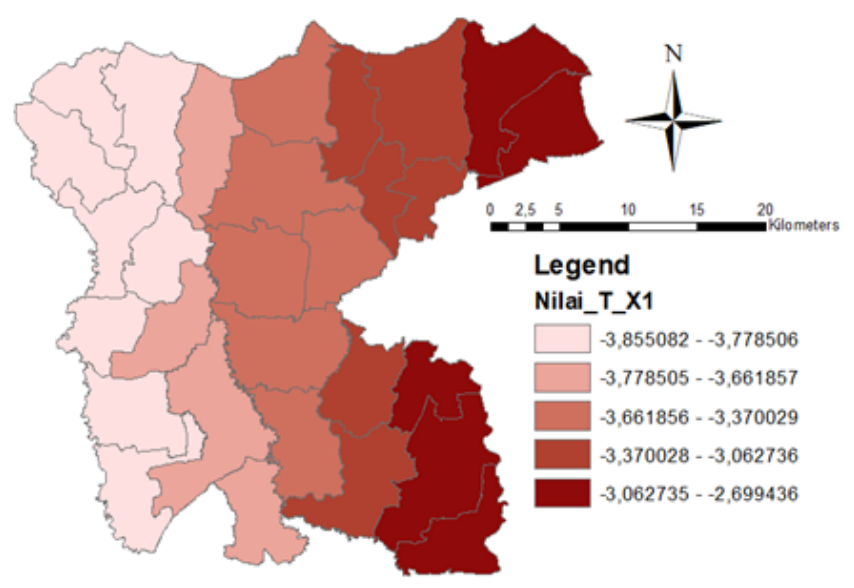

banyaknya masyarakat yang bermigrasi untuk mencari pekerjaan.

Pertumbuhan penduduk akan meningkatkan land mand ratio yang menyebabkan terjadinya perebutan akan lahan untuk kegiatan masyarakat seperti permukiman dan perekonomian. Perebutan lahan yang terjadi di daerah perkotaan memaksa masyarakat untuk mencari permukiman ke luar kota (pedesaan) akibat tingginya nilai lahan di perkotaan. Secara tidak langsung akan meningkatkan kepadatan penduduk di area pinggir perkotaan dan menghasilkan permintaan kebutuhan akan lahan yang merupakan fungsi dari kepadatan penduduk (Pakpahan \& Anwar, 1989). Dampak dari aktivitas migrasi masyarakat untuk mencari permukiman di luar perkotaan ialah timbulnya alih fungsi lahan yang semula digunakan untuk pertanian diubah menjadi daerah permukiman (Harini et al., 2013).

Pengujian nilai-t kepadatan penduduk dengan signifikansi sebesar 0,05 menghasilkan 24 kecamatan di Kabupaten Tangerang berpengaruh signifikan terhadap konversi lahan pertanian. Terdapat empat kecamatan yang tidak berpengaruh signifikan antara lain ialah Kecamatan Gunungkaler, Mekarbaru, Kemiri dan Jayanti.

Pada gambar 5, menampilkan persebaran nilai variabel rumah tangga miskin di setiap kecamatan. Kemiskinan menjadi salah satu faktor terjadinya konversi lahan pertanian, khsusunya pada daerah perdesaan. Hal ini dikarenakan sudah menjadi cerita klasik mayoritas pelaku

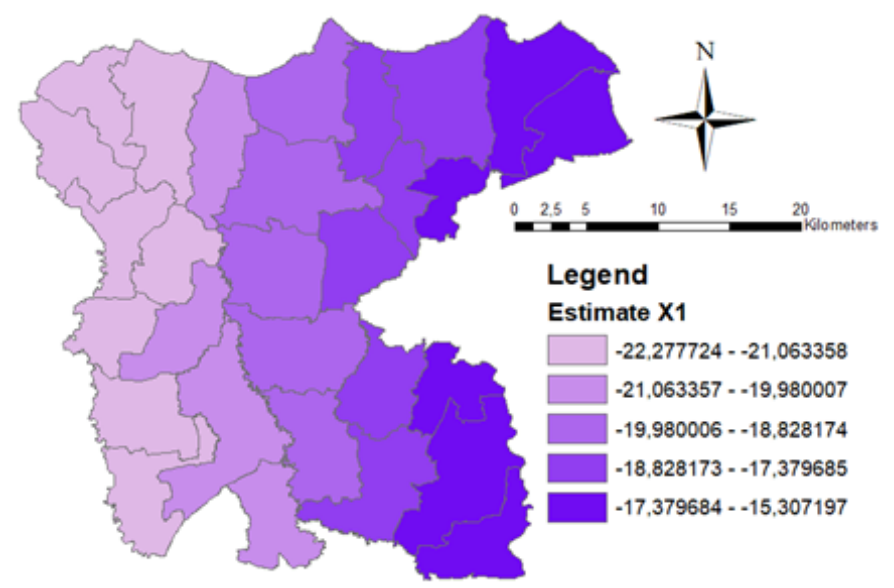

Gambar 3. Peta sebaran lokal nilai-t dan estimasi X1.
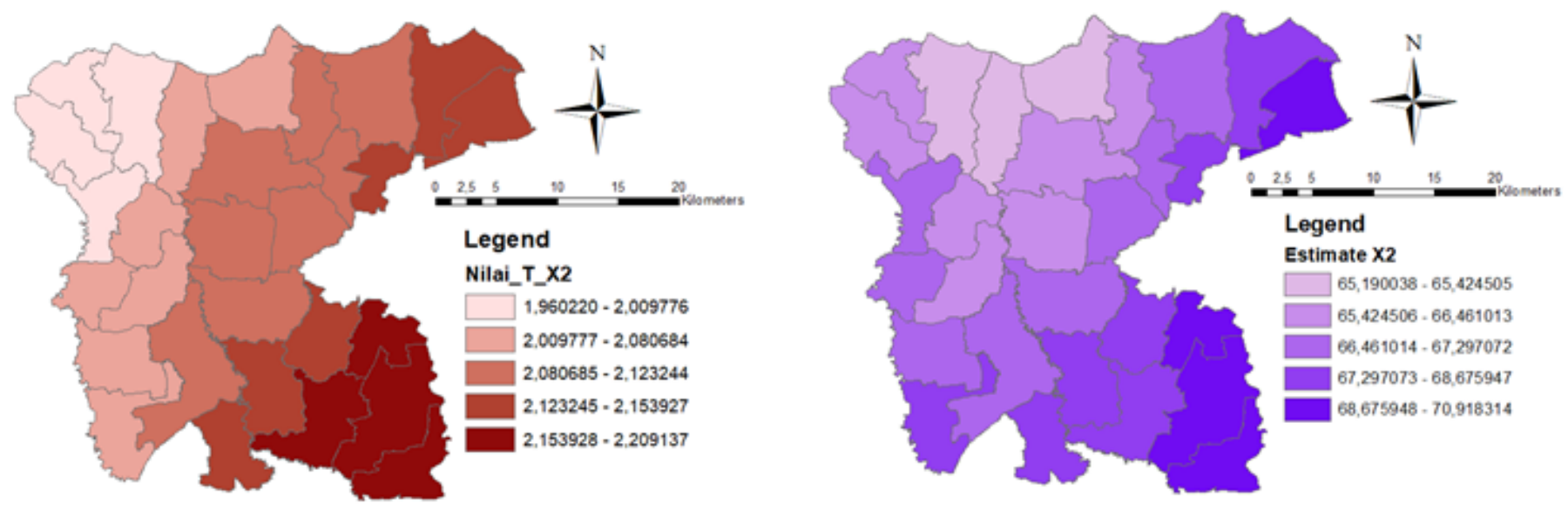

Gambar 4. Peta sebaran lokal nilai-t dan estimasi kepadatan penduduk (X2). 

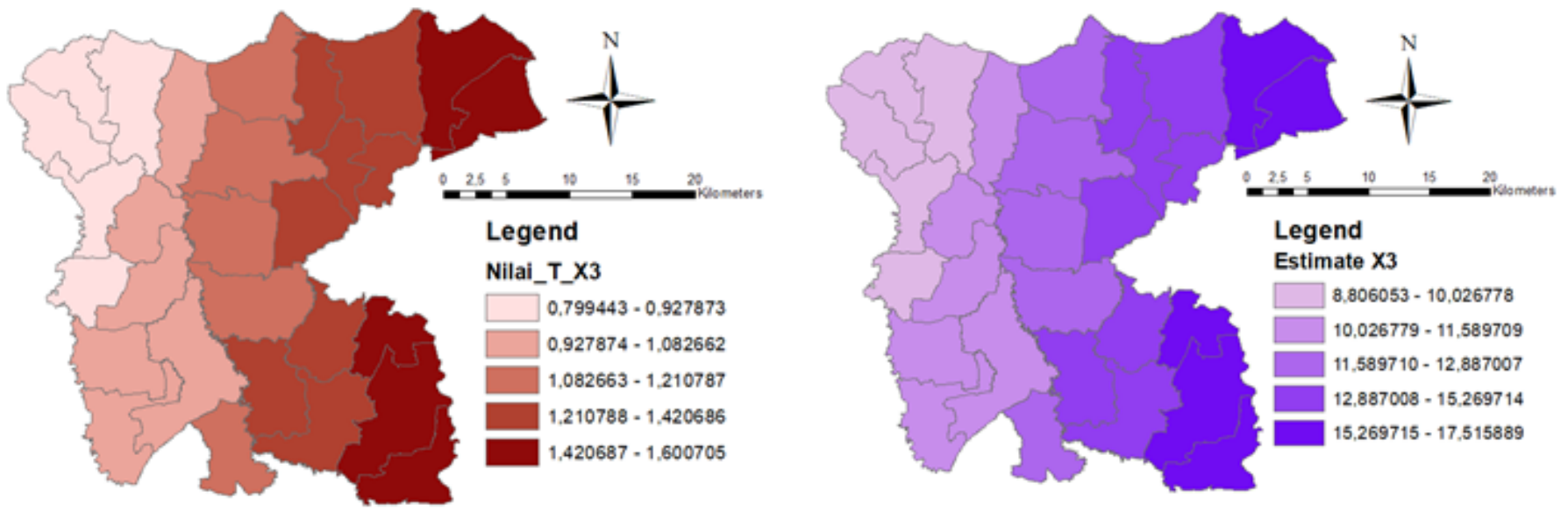

Gambar 5. Peta sebaran lokal nilai-t x3 dan estimate Rumah Tangga Miskin (X3).

Tabel 11. Variabel Berpengaruh

\begin{tabular}{ll}
\hline Variabel Prediktor & Kecamatan \\
\hline $\mathrm{X} 1$ & Gunung Kaler, Mekarbaru, Kemiri dan Jayanti \\
$\mathrm{X} 1$ dan X2 & Kosambi, Teluknaga, Pakuhaji, Sepatan, Sepatan Timur, Cisoka, Cisauk, \\
& Pagedangan, Kelapa Dua, Curug, Balaraja, Legok, Tigaraksa, Jambe, Sin- \\
& dangjaya, Mauk, Panongan, Rajeg, Solear, Sukamulya, Kronjo, Kresek, \\
& Kemiri, Cikupa dan Sukadiri \\
\hline
\end{tabular}

Sumber : Hasil Penelitian (2020)

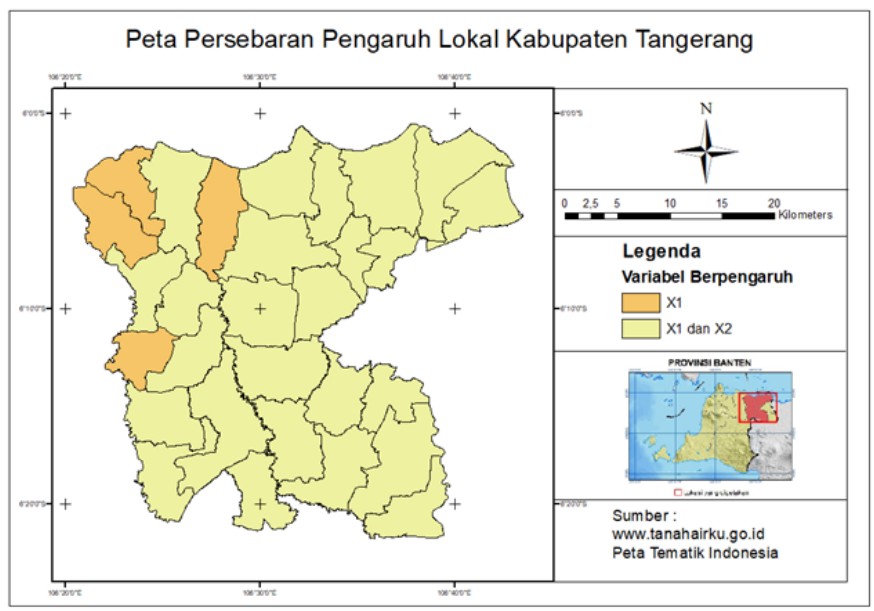

Gambar 6. Peta Persebaran Pengaruh Lokal Kabupaten Tangerang

usaha pertanian adalah petani pedesaan dengan keadaan miskin, berpendidikan rendah, lahan usaha taninya sempit (Sumaryanto, Friyatno, \& Irawan, 2001)

Penguasaan lahan sempit akan memberikan imbal hasil yang didapatkan tidak sebanding dengan pengorbanan yang dilakukan. Masyarakat akan mencari cara untuk penghidupan dan kesejahteraan mereka secara cepat. Upaya yang dilakukan dengan menjual tanah yang dimiliki untuk mendapatkan keuntungan yang lebih tinggi dari penjualan ke sektor industri dibandingkan harga jual untuk persawahan (Prihatin, 2015). Terutama kemiskinan yang dirasakan oleh masyarakat petani pangan yang mengisi 75 persen dari petani miskin (Arifin, 2006). Pada pengujian nilai-t dengan taraf signifikansi 0,05 tidak ditemukan adanya pengaruh signifikan terhadap alih fungsi lahan petanian di seluruh kecamatan.
Berdasarkan hasil tersebut, maka dapat dibuat kluster wilayah per kecamatan yang didasarkan banyaknya variabel yang mempengaruhi konversi lahan pertanian. Hasil pengujian yang berupa nilai-t kemudian diuji menggunakan taraf signifikansi sebesar 0,05 . Hasil yang didapatkan ialah banyaknya variabel prediktor yang berpengaruh pada tingkat kecamatan. Keseluruhan hasil pengujian dapat dilihat dalam tabel 11

Sebagian besar kecamatan yang berpengaruh sebanyak dua variabel terletak tidak jauh dari pusat perekonomian. Khususnya daerah yang berdekatan dengan kawasan industri kota Tangerang dan area perdagangan serta jasa di Kota Tangerang Selatan. Hasil dari pengujian variabel pengaruh signifikan tersebut dapat dilihat dalam bentuk gambar 6 .

\section{KESIMPULAN}

Berdasarkan hasil pengujian dan pemodelan yang dilakukan dalam penelitian, maka dapat disimpulkan bahwa terdapat dua faktor eskternal yakni laju pertumbuhan penduduk dan kepadatan penduduk yang berpengaruh signifikan terhadap konversi lahan pertanian di 25 kecamatan. Faktor laju pertumbuhan penduduk diketahui hanya berpengaruh signifikan terhadap konversi lahan pertanian di Kecamatan Gunungkaler, Kemiri, Jayanti dan Mekarbaru. Rumah tangga miskin tidak berpengaruh signifikan pada seluruh kecamatan di Kabupaten Tangerang. Sebagai saran dalam penelitian selanjutnya untuk mendapatkan hasil pengaruh konversi lahan pertanian yang lebih komperehensif, perlu penggunaan faktor lain selain yang digunakan dalam penelitian ini. Pengkajian mengenai faktor internal dan kebijakan pemerintah seperti kebijakan Rencana Tata Ruang Wilayah (RTRW) serta arah pembangunan perekonomian pemerintah akan turut menyempurnakan hasil penelitian ini. 


\section{DAFTAR PUSTAKA}

Anshori, M., \& Iswati, S. (2017). Metode Penelitian Kuantitatif. Surabaya: Airlangga University Press.

Arifin, B. (2006). Pemikiran untuk Mengeluarkan Petani Dari Kemiskinan. Jurnal Pangan, 15(46), 3-14. https://doi.org/https:// doi.org/10.33964/jp.v15i1.278

BPS Kabupaten Tangerang. (2019). Kabupaten Tangerang Dalam Angka 2019. Kabupaten Tangerang: BPS Kabupaten Tangerang.

BPS Provinsi Banten. (2019a). Luas Lahan Menurut Penggunaanya Provinsi Banten. Serang: BPS Provinsi Banten.

BPS Provinsi Banten. (2019b). Provinsi Banten Dalam Angka 2019. Serang: BPS Provinsi Banten.

Brunsdon, C., Fotheringham, A. S., \& Charlton, M. E. (1996). Geographically Weighted Regression: A Method for Exploring Spatial Nonstationary. Geographical Analysis, 28(4). https:// doi.org/https://doi.org/10.1111/j.1538-4632.1996.tb00936.x

Darwis, V. (2008). Keragaan Penguasaan Lahan Sebagai Faktor Utama Penentu Pendapatan Petani. Dinamika Pembangunan Pertanian Dan Perdesaan: Tantangan Dan Peluang Bagi Peningkatan Kesejahteraan Petani Bogor, 19 Nopember 2008, 158-175. Pusat Analisis Sosial Ekonomi dan Kebijakan Pertanian. Retrieved from http://pse.litbang.pertanian.go.id/ind/pdffiles/ MS_A9.pdf

Djoni, Suprianto, \& Cahrial, E. (2016). Kajian Alih Fungsi Lahan Pertanian Pangan di Kota Tasikmalaya. Mimbar Agrisbinis, 1 (3), 233-244. https://doi.org/http://dx.doi.org/10.25157/ ma.vli3.43

Fadjarajani, S. (2008). Dinamika Masyarakat Dan Konversi Lahan Pertanian Serta Pengaruhnya Terhadap Pengetahuan Tentang Lingkungan Di Kawasan Bandung Utara. Majalah Geografi Indonesia, 22(2), 102-123. https://doi.org/10.22146/mgi.13319

Fadjarajani, \& Singkawijaya. (2019). Agricultural Conversion Phenomenon to Non-Agricultural Land in Tasikmalaya City. International Journal of Innovation, Creativity and Change, 9(1), 157 $-166$.

Harini, R., Yunus, H. S., Kasto, \& Hartono, S. (2012). Agricultural Land Conversion: Determinants and Impact for Food Sufficiency in Sleman Regency. Indonesian Journal of Geography, 44(2), 120-133. https://doi.org/10.22146/indo.j.geog,2394

Huang, B., Wu, B., \& Barry, M. (2010). Geographically and temporally weighted regression for modeling spatio-temporal variation in house prices. International Journal of Geographical Information Science, 24(3), 383-401. https:// doi.org/10.1080/13658810802672469

Idjudin, A. A., \& Marwanto, S. (2008). Reformasi Pengelolaan Lahan Kering Untuk Mendukung Swasembada Pangan. Jurnal Sumberdaya Lahan, 2(2). Retrieved from http:// balittanah.litbang.pertanian.go.id/ind/index.php/publikasimainmenu-78/art/253-kering

Ikhwanto, A. (2019). Alih Fungsi Lahan Pertanian Menjadi Lahan Non Pertanian. Jurnal Hukum Dan Kenotariatan, 3(1), 60-73. https://doi.org/10.33474/hukeno.v3i1.1919

Ilham, N., Syaukat, Y., \& Friyatno, S. (2005). Perkembangan dan Faktor-faktor yang Mempengaruhi Konversi Lahan Sawah Serta Dampak Ekonominya. SOCA: Jurnal Sosial Ekonomi Pertanian, 5(2). Retrieved from https://ojs.unud.ac.id/index.php/soca/ article/view/4081

Irawan, B., \& Ariningsih, E. (2015). Dinamika Kebijakan dan Ketersediaan Lahan Pertanian. Panel Petani Nasionald: Mobilisasi Sumberdaya Dan Pengetahuan Kelembagaan Pertanian, 925. Badan Penelitian dan Pengembangan Pertanian.

Irawan, B., \& Pranadji, T. (2002). Pemberdayaan Lahan Kering untuk Pengembangan Agribisnis Berkelanjutan. Forum Penelitian Agro Ekonomi, 20(2), 60-76. https://doi.org/10.21082/ fae.v20n2.2002.60-76

Kurniasari, M., \& Ariastita, P. G. (2014). Faktor - Faktor yang Mempengaruhi Alih Fungsi Lahan Pertanian Sebagai Upaya Prediksi Perkembangan Lahan Pertanian di Kabupaten Lamongan. Jurnal Teknik ITS, 3(2), 119-C124. https:// doi.org/10.12962/j23373539.v3i2.7237
Lu, B., Charlton, M., Harris, P., \& Fotheringham, A. S. (2014). Geographically Weighted Regression with a Non-Euclidean Distance Metric: A Case Study Using Hedonic House Price Data. International Journal of Geographical Information Science, 28 (4), 660-681. https://doi.org/10.1080/13658816.2013.865739

Lutfi, A., Aidid, M. K., \& Sudarmin. (2019). Identifikasi Autokorelasi Spasial Angka Partisipasi Sekolah di Provinsi Sulawesi Selatan Menggunakan Indeks Moran. Variansi: Journal of Statistics and Its Application on Teaching and Research, 1(2), 1-8. https://doi.org/https://doi.org/10.35580/variansi.v1i2.9354

Mennis, J. (2006). Mapping the results of geographically weighted regression. Cartographic Journal, 43(2), 171-179. https:// doi.org/10.1179/000870406X114658

Pakpahan, A., \& Anwar, A. (1989). Faktor-Faktor yang Mempengaruhi Konversi Lahan Sawah. Jurnal Agro Ekonomi, 8 (1), 62-74.

Prabowo, R., Bambang, A. nur, \& Sudarno. (2020). Pertumbuhan Penduduk Dan Alih Fungsi Lahan Pertanian. Jurnal Ilmu-Ilmu Pertanian, 16(2), 26-36. https://doi.org/http:// dx.doi.org/10.31942/md.v16i2.3755

Prihatin, R. B. (2015). Alih Fungsi Lahan Di Perkotaan (Studi Kasus Di Kota Bandung Dan Yogyakarta). Jurnal Aspirasi, 6(2), 105118. https://doi.org/10.22212/aspirasi.v6i2.507

Saefuddin, A., Setiabudi, N. A., \& Achsani, N. A. (2011). On comparisson between ordinary linear regression and geographically weighted regression: With application to indonesian poverty data. European Journal of Scientific Research, 19(2), 205-210. Retrieved from https://repository.ipb.ac.id/ handle/123456789/54587

Sayeed, A. (2014). Causes and Consequences of Land Degradation Causes and consequences of land degradation $\nabla$ : A case study on 'Keyain 'village of Mushigonj District. Sodertorn University.

Sumaryanto, Friyatno, S., \& Irawan, B. (2001). Konversi Lahan Sawah ke Penggunaan Non Pertanian dan Dampak Negatifnya. Prosiding Seminar Nasional Multifungsi Lahan Sawah, 1-18. Retrieved from http://balittanah.litbang.pertanian.go.id/ind/

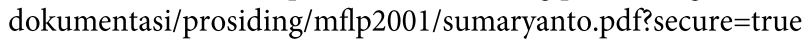

Tobler, W. R. (1970). A Computer Movie Simulating Urban Growth in the Detroit Region. Economic Geography, 46, 234-240. https://doi.org/10.2307/143141

Wunarlan, I., \& Syaf, H. (2019). Analisis Pengaruh Pertumbuhan Penduduk dan Produktivitas Lahan Terhadap Alih Fungsi Lahan Perkotaan (Studi Kasus Kota Marisa). Jurnal Perencanaan Wilayah, 4(1), 1-11. https://doi.org/http://dx.doi.org/10.33772/ jpw.v4i1.7464 